\title{
Iscenesettelse av barnehagens lekemiljo - fra nye erfaringer til eksperimenterende og utforskende praksis
}

\author{
Anette Sofie Bernsen, ${ }^{\star 1}$ Amund Langøy ${ }^{2}$ og Margareth Eilifsen ${ }^{3}$ \\ ${ }^{1} N L A$ Høgskolen / Universitetet $i$ Sørøst-Norge, Norge; ${ }^{2} N L A$ Høgskolen / Universitetet $i$ \\ Bergen, Norge og ${ }^{3}$ Høgskulen på Vestlandet, Norge
}

\begin{abstract}
SAMMENDRAG
Artikkelen bygger på konteksttilpasset intervensjonsdesign i en barnehage som jobber aktivt med barnehagens lekemiljø. Hele forskningsprosjektet er gjennomført av tre faglærere innen fagene drama, pedagogikk og fysisk fostring i barnehagelærerutdanningen. Avdelinger i barnehagen ble transformert og iscenesatt av ulike materialer og visuelle elementer. Formålet var å designe alternative løsninger som konsept til tradisjonelle etablerte lekerom. Studien drøfter personalets aktive deltagelse i intervensjonene, og hva som skaper motivasjon og forståelse av rommets betydning for pedagogisk praksis. Studien kan bidra til eksisterende kunnskap ved å se på nye perspektiver og tilnærminger til barnehagelærerrollen. Datamaterialet består av observasjoner som ble gjort under to personalsamlinger, to fokusgruppeintervjuer og forskningsdagbok fra prosjektet med et forløp på ett år. Det teoretiske grunnlaget for studien er Deci og Ryan (2000) sin selvbestemmelsesteori, og det empiriske materialet er analysert med utgangspunkt i David Kolb (2015) sine refleksjoner rundt erfaring som ressurs for læring og utvikling. Funnene viser at egne kroppslige erfaringer og aktiv deltagelse i kollektive prosesser over tid skaper motivasjon for endring i den pedagogiske praksisen hos personalet. Økt kompetanse med eksperimentering med lekemiljøer fører til indre regulert motivasjon. Personalet motiveres av barnas entusiasme, som igjen fører til større grad av medvirkning for barna i eget lekemiljø. Det skapes en delingskultur for kreativitet i tilretteleggingen av barnas lekemiljø.
\end{abstract}

Nøkkelord: intervensjon; kroppslig erfaring; lekerom; motivasjon

Mottatt: November, 2020; Akseptert: Mai, 2021; Publisert; August, 2021

\begin{abstract}
Staging play environment in the early childhood education and care (ECEC) institutions - from new experiences to experimental and exploratory practices

This article concerns structured intervention design in early childhood education and care (ECEC) institutions. This research project is conducted by three lecturers of drama, pedagogy,
\end{abstract}




\section{A. S. Bernsen, A. Langøy E̋ M. Eilifsen}

and physical education within the field of early childhood education. Traditional play environments were transformed and staged with various materials and visual designs, which exemplified alternative conceptual solutions. This study discusses the staff's active participation and it also discusses which factors create motivation and understanding concerning the importance of space and environment in pedagogical practice. This study contributes to the existing knowledge on this topic by focusing on new perspectives about the role of the teacher. The data material was gathered from two focus group interviews and from field observation and notes during the course of a year. The theoretical framework for this research is based on self-determination theory (Deci \& Ryan, 2000) and on David Kolb's experiential learning cycle (2015). Our findings may indicate that motivation among staff, for changing the pedagogical practice, results from their embodied experience as they actively participate in a collective process over time. Increased competence in experimenting with play environments produces internally regulated motivation. Motivation is fostered among staff as they observe the children's enthusiasm with the new playrooms. The enthusiasm leads to a greater degree of children's participation and influence. A culture of sharing ensues among the staff regarding facilitating creativity in the children's play environment.

Keywords: embodied; experience; intervention; motivation; playroom

\section{Innledning}

\section{Samarbeid om endringer i lekemiljøet}

Jeg synes det var bra med dette at alle deltar. Det er utrolig vanskelig hvis du sender to-tre på kurs og så skal de komme tilbake og brenne veldig for det og skal implementere det. Det er nesten umulig. (Barnehagelærer)

Utsagnet innledningsvis er hentet fra et fokusgruppeintervju med barnehagelærere fra et tverrfaglig forskningsprosjekt mellom faglærere innen fagene drama, pedagogikk og fysisk fostring i barnehagelærerutdanningen. Vi undersøkte hvordan en personalgruppe utforsket og eksperimenterte med lekemiljøet i barnehagen, med omfang på ett år. Lekemiljøet hadde en sentral plass i den praktiske virksomheten ved den aktuelle barnehagen. Den pedagogiske praksisen i norske barnehager skal, i tråd med stortingsmeldingen Tid for lek og lering, inkludere alt barna møter i barnehagen som en del av barnehagens innhold (Meld. St. 19 (2015-2016)). I barnas hverdag er det personalet som definerer hvilken praksis som skal få råde i barnehagen. Ifølge Rammeplanen for barnehagens innhold og oppgaver skal personalet jobbe med et varierende og stimulerende tilbud i barnas lekemiljø (Kunnskapsdepartementet, 2017). Forskningsprosjektet Gode barnehager for barn $i$ Norge $(\mathrm{GoBaN})$ viser at det er store kvalitetsforskjeller i barnehagene (www.goban.no). Det eksisterer barnehagemiljøer med lite passende og tilgjengelige rom og materiell. Det er blant annet forskjeller på hva som blir vektlagt fra personalets side og på samspillet mellom voksne og barna (Bjørnestad \& Os, 2018; Nordin-Hultmann, 2004). Det er i samspillet mellom voksne og barn og hverdagsmiljøet at læring skjer. Derfor bygger vi studien vår på et sosiokulturelt perspektiv, der læring skjer i interaksjon mellom individer, og mellom individer og redskaper (Ødegård et al., 2017). Studien ser nærmere på hvordan kroppslige erfaringer kan ha betydning for barnehagelærerens motivasjon for arbeid 
med endringer av barnehagens lekerom. Det teoretiske grunnlaget bygger på erfaringslæring av David Kolb (2015), med tanker rundt konkret erfaring som ressurs for læring og utvikling. Erfaringslæring i en utforskende praksis ses i sammenheng med sentrale perspektiver knyttet til forståelsen av autonomi og motivasjon for endring (Deci \& Ryan, 2000).

Prosessen med å finne egne løsninger i rommene for og sammen med barnegruppene startet når personalet selv deltok i intervensjoner. En intervensjon kunne for eksempel være å iscenesette tematiske rom, og ha leketemaer både inne og ute som kunne stimulere til både fysisk aktivitet, opplevelser og nye lekesituasjoner. Erfaringene med å gjøre forandringer i lekemiljøet ble fulgt opp med samtaler med personalet. Hele personalet deltok i intervensionen, mens en fokusgruppe med seks barnehagelærere og styrer fungerte som referansegruppe for studien.

Med dette som utgangspunkt ble forskningsspørsmålet: Hvordan kan barnehagelæreres aktive deltagelse i et prosjekt om endringer av lekemiljøet skape motivasjon og forståelse av rommets betydning for pedagogisk praksis?

\section{Tidligere forskning på det fysiske miljø i pedagogisk praksis}

Flere forskere skriver om den betydningen hverdagsliv og barnehagens fysiske miljø har for barn (Grindheim, 2014; Moser, 2012; Nordin-Hultman, 2004; Nordtømme, 2016; Sando \& Sandseter, 2020). Foreliggende litteratur tar utgangspunkt i at rommet, altså det fysiske lekemiljøet, påvirker barna og hvordan de må forholde seg til rommet og det som er plassert der. Thomas Moser (2012) understreker personalets rolle ved utvikling, endring og det å skape nye rom i barnehagen. Bjørnestad og Os (2018) finner at flere barnehager ikke har nok materiell som er egnet til lek og læring, og at barnehagens organiseringsform kan påvirke mangelen på lekemateriell. Videre fremmes det hvordan gode lekesoner og et bredt spekter av lekeaktiviteter er viktige for trivselen til barna (Sando \& Sandseter, 2020). Solveig Nordtømme (2016) vektlegger i sin doktorgradsavhandling hvordan barnas lek og danning påvirkes av barnehagens rom og de gienstandene som finnes der. Rom og materialitet kan være en pedagogisk ressurs i barnehagen, og Nordtømme fremhever det som skjer i samhandlingen mellom barnet og rommet: «Når barn tar rommet i bruk, skapes det sansing, bevegelse og samhandlinger. Rom og materialitet settes i spill som giør at noe skjer, og rommet får betydning på nye måter» (Nordtømme, 2016, s. 11).

Nordtømme støtter seg til en kroppsfenomenologisk tilnærming til rom, der kroppens tilstedeværelse i verden er det sentrale. Kroppsfenomenologi er først og fremst knyttet til filosofen Maurice Merleau-Ponty, som tar utgangspunkt i tenkningen om livsverdenen, der kroppen er utgangspunkt for all erfaring (Merleau-Ponty, 1945/1994). En slik tilnærming giør det mulig å se på rommet som et sted for levd erfaring, lek og sansning, slik det trer frem for og kommer mennesket i møte, og der kroppens tilstedeværelse i verden er det sentrale i pedagogiske situasjoner (Nordtømme, 2016). 


\section{A. S. Bernsen, A. Langøy E M. Eilifsen}

Bernsen (2017) presenterer et perspektiv på de eldste barna som ressurser ved at de involveres i planlegging og konstruksjonen av å skape et annerledes lekerom for de aller yngste barna. Hun finner også at hele personalgruppen burde inkluderes i prosjektet om rommet, med vekt på faglig diskusjon i personalet. Ødegård et al. (2017) setter søkelyset videre på kvalitet i barnehagen og peker på at personalets fellesskap er sentralt når en skal bygge kollektiv kompetanse i en lærende barnehage. Øvreås et al. (2020) viser til at en konteksttilpasset intervensjon der fellesskapet er viktig og hele personalgruppen blir inkludert, har positive effekter på det kollegiale samspillet og erfaringsdelingen. Perspektivet på personalets rolle i tilknytning til rom og materialitet utvides gjennom didaktiske kontekster hvor hele personalgruppen er deltagere med felles erfaring i eksperimentering av lekemiljøet.

\section{Teoretisk referanseramme - fra konkret erfaring til eksperimentering}

David Kolb $(2000,2012,2015)$ har utviklet en teori om erfaringslæring med utgangspunkt i tanker fra John Dewey, Jean Piaget og Kurt Lewin. Kolb ser på læring som en vedvarende, helhetlig prosess hvor erfaring omdannes til kunnskap, og han hevder at all læring er erfaringsbasert. Kolbs erfaringslæringsmodell representerer en sirkulær læringsprosess som dreier seg om prosess og struktur.

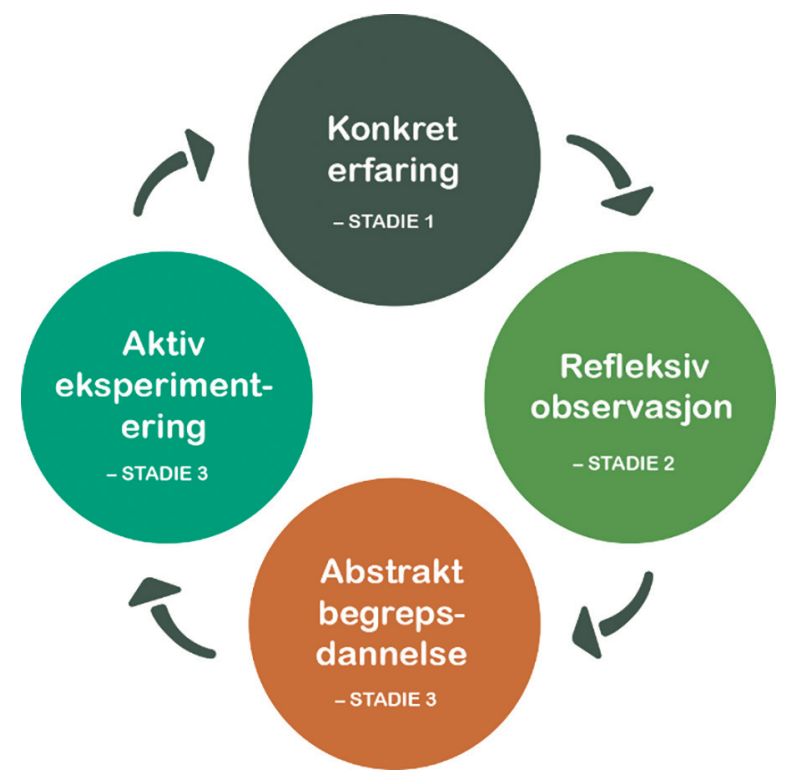

Figur 1. Kolbs (2012) forenklete modell for erfaringslæring.

Læringsprosessen består av fire stadier eller tilpasningsformer benevnt som (1) konkrete erfaringer, (2) opplevelses-reflekterende observasjon, (3) abstrakt begrepsdannelse og 4) aktiv eksperimentering. I første stadium er det selve erfaringen som 
er grunnlag for læringen, men modellen til Kolb viser også at alle stadiene henger sammen og påvirker hverandre. Etter den konkrete erfaringen kommer det en refleksjon over handlingen, eller over opplevelsen. Abstrakt begrepsdannelse speiler analyseprosessen og innebærer å løfte refleksjonen og knytte den til teori på en adekvat måte. Det siste stadiet innebærer aktiv eksperimentering og utprøving, hvor refleksjonene kan settes ut i konkret handling som igjen fører til en ny konkret erfaring (Kolb, 2012). Erfaringslæring er en prosess der ny kunnskap, nye ferdigheter og nye holdninger blir skapt gjennom konfronterende møter mellom de fire stadiene. Læringsprosessens strukturelle grunnlag ligger i transaksjoner mellom de fire tilpasningsformene og hvordan motsetninger mellom disse løses. Erfaringssirkelen er også en spiral; den åpner opp for at sirkelen kan gjennomføres flere ganger, og da med ny innsikt som bygger på nyervervet innsikt og erfaring.

I selvbestemmelsesteorien (Deci \& Ryan, 2000) knyttes opplevelsen av tre grunnleggende psykologiske behov (kompetanse, autonomi og tilhørighet) til ulike former for motivasjon. Her defineres motivasjon i ulike kategorier ut ifra hvor indre eller ytre regulert motivasjonen er (Ryan \& Deci, 2017). Dersom en i stor grad opplever å få tilfredsstilt sine behov, vil motivasjonen kunne bli mer indre styrt. På andre siden, dersom en i liten grad opplever tilfredsstilte behov, vil en utvikle en ytre regulert motivasjon, eller fravær av motivasjon, sistnevnte kalles også amotivasjon (Deci \& Ryan, 2000). Miljø som tilrettelegger for at mennesker får dekket de tre nevnte behovene omtales som autonomistøttende motivasjonsklima. Å være indre motivert, altså å synes noe er gøy å holde på med, har vist seg å være en form for motivasjon som gir positive konsekvenser som innsats, utholdenhet og velvære (Deci \& Ryan, 2000).

\section{Forskningsdesign og metode}

Artikkelen bygger på empiri og analyser fra en intervensjonsstudie, og studien er en kvalitativ designstudie med utgangspunkt i konteksttilpasset intervensjonsforskning (Akker et al., 2006). Tre forskere gjennomførte studien i en barnehage med 145 barn og 40 ansatte. Barnehagen tok selv kontakt og ønsket et forskningssamarbeid. Intervensjonen bygger på tidligere undersøkelser av Bernsen et al. (2014), og metoden gir barnehagelærerne en aktiv rolle i utforming og gjennomføring av intervensjonen (Øvreås et al., 2020). Intervensjonsforskning er forskning som søker å måle forandring i noe eller noen (O’Toole, 2006), som i denne studien er en handlings- eller medvirkningsforandring i barnehagens pedagogiske praksis. Intervensjonsforskning har likheter med aksjonsforskning ved at hele personalgruppen engasjeres aktivt $\mathrm{i}$ endringsarbeid. Det skapes samtidig ny innsikt og kunnskap som senere kan implementeres i den videre virksomheten (Bøe \& Thoresen, 2017). I første del av intervensjonen vår var hele personalgruppen samlet. Vi gjennomførte en workshop der deltagerne fikk en konkret opplevelse i tillegg til teoretisk forelesning. Det ble først forelest om motivasjon, rom og erfaringskompetanse, før det ble gjennomført en praktisk aktivitet $\mathrm{i}$ tre ulike rom. Aktiviteten var å være i lek inne på de ulike rommene 


\section{A. S. Bernsen, A. Langøy \& M. Eilifsen}

i 5 minutter. To av romutformingene hadde ulike scenografiske løsninger. Scenografi i denne sammenhengen betød transformerte rom med visuell utforming som skapte en tematisk kontekst, ment for interaksjon som innbydde til deltagelse.

Det ble skapt to ulike tematiske scenografier eller romtransformasjoner: et papirrom og et rør-og ballrom, ${ }^{1}$ samtidig var deltagerne også i et tradisjonelt rom som beholdt sitt uttrykk og innredning, med leketilbud som var der fra før. Oppsummert ble personalet presentert for to alternative konsepter til et tradisjonelt etablert lekerom, samtidig som de fikk erfaringer fra det tradisjonelle lekerommet. Personalet deltok ikke ved konstruksjonen av rommene, men kom inn som deltagere i scenografiene. På denne måten fikk personalet en umiddelbar opplevelse ved at deres vante arbeidsmiljø hadde blitt transformert.

Det empiriske materialet ble innhentet gjennom forskningsdagbok og fokusgruppeintervju. Prosjektperioden gikk over ett år, og to fokusgruppeintervju ble gjennomført med tre måneders mellomrom i samme periode. I prosjektperioden skulle personalet skape egne intervensjoner med nye lekemiljøer og scenografier. Tema for de to fokusgruppeintervjuene var refleksjoner rundt arbeidet med disse intervensjonene, og intervjuene ble gjennomført tre og seks måneder etter oppstartsamlingen. Fokusgruppen bestod av pedagogiske ledere og styrer fra hver avdeling (samme gruppe deltok i begge intervjuene). Fokusgruppeintervjuene startet med åpne spørsmål rundt gruppens erfaringer med intervensjonene de hadde deltatt $i$, og intervjuene ble ledet av en av forskerne. Det var frivillig å delta i fokusgruppen, og alle fikk informasjon om at de kunne trekke seg underveis i prosjektet. Intervjuene la vekt på personalgruppens erfaringer med sine egne pågående intervensjoner, dokumenter med bilder og video. Fokusgruppeintervjuene ble tatt opp på bånd, transkribert og deretter slettet. Prosjektet ble meldt til, og godkjent av, Norsk senter for forskningsdata (NSD).

Fokusgruppeintervjuene ble gjennomført med halvstrukturerte spørsmål, og forskningsdagboken ble ført som logg etter deltagende observasjoner sammen med hele personalgruppen. På den måten har vi styrket reliabiliteten i forskningen og styrket påliteligheten i data fra fokusgruppeintervjuene.

\footnotetext{
${ }^{1}$ Det ene rommet ble utformet som et rør- og ballrom. En stor, blå ballong henger ned fra taket. Små ballbingeballer plasseres på gulvet og oppi bøtter, og det ligger flere dren-rør lett tilgjengelig. En tunnel til å krype gjennom er plassert på gulvet. Blått stoff dekker bordene og lager et nytt rom i rommet. Den andre avdelingen blir transformert og iscenesatt til et papirrom. Med en hvit papirrull kles deler av rommet fra tak til gulv. En strandstol og en gammel koffert er trukket med avispapir. Stolen plasseres under et tak formet av papir. Ved siden av strandstolen plasseres en krone laget av gafler. Kofferten, som er fylt med svamper, er åpen. Vannmaling står tilgjengelig på et bord i rommet. Rolig instrumentalmusikk spilles i papirrommet, mens popmusikk-rytmer tilføres ballrommet.
} 


\section{Analyse}

Analyseprosessen startet med en gjennomgang av det innsamlete datamaterialet, som bestod av notater fra en forskningsdagbok fra deltagende observasjon og to fokusgruppeintervjuer. Data ble gjennomlest individuelt og i fellesskap. For å svare på forskningsspørsmålet så vi etter uttrykk for hvordan barnehagelæreres aktive deltagelse i et prosjekt om endringer av lekemiljøet kan skape motivasjon og forståelse av rommets betydning for pedagogisk praksis. Vi kartla relevante utsagn og tendenser fra fokusgruppeintervjuene gjennom tematisk analyse, og den transkriberte teksten ble vurdert opp mot teori (Finlay, 2014). Tematikken som trådte frem gjennom analyseprosessen fikk egne overskrifter. I første koding av fokusgruppeintervjuet fant vi ordene aha-opplevelse; å kjenne på; rommet gjør noe med deg i tilknytning til kroppslige erfaringer som refleksjon. Utsagnene som hører sammen ble satt i kategorier, noe som er i tråd med hva Kvale og Brinkmann (2015) kaller global mening, der ord og tema gjentas i særlig grad og blir ansett som mønstre eller tematikk. I andre koding fremtrådte ord som kreativ og kompetanse, noe som peker på indre regulert motivasjon. Utsagnene kan ikke tolkes som sannheter, men som erfaringer personalet selv sitter igjen med. Det transkriberte materiale fra fokusgruppeintervjuene ble sendt til deltagerne av intervjuene for gjennomlesing, godkjenning og med mulighet for innspill. Fokusgruppeintervjuene kan ikke representere hele personalgruppens erfaringer, men gjengir fokusgruppens egne uttrykk og fortolkninger fra prosessen.

I den følgende delen presenteres utvalgte funn. Til hvert enkelt funn knyttes en kort teoretisk redegjørelse. Etter denne delen vil vi drøfte funnene opp mot tidligere forskning og i lys av vårt teoretiske rammeverk.

\section{Funn og diskusjoner}

\section{Funn 1: Aktiv deltager - kroppslig erfaring som refleksjon}

I første koding vektlegges utsagn fra fokusgruppen som omhandler kroppslige erfaringer. Følgende utsagn fra en barnehagelærer gjenspeiler erfaring fra en selvopplevd workshop med transformert lekemiljø:

Jeg fikk en aha-opplevelse av hvordan ungene har det med å komme inn i sånne rom, vi fikk kjenne på det selv. Det har vært en inspirasjon. Det utvider horisonten litt på hva man kan tenke hvis man ikke har jobbet noe særlig med det før.

Det å få en aha-opplevelse kan si noe om en umiddelbar kroppslig reaksjon hos de involverte. Sitatet viser at barnehagelæreren får utvidet horisonten sin gjennom nye erfaringer. På dette tidspunktet var barnehagelærerne i første stadium av Kolbs erfaringslæringssirkel. Utsagnet over kan knyttes til første del av syklusen, som handler om å etablere kroppslige erfaringer og følelser i det romlige møtet. De iscenesatte rommene skulle gi impulser til nye ideer og åpne for nye muligheter: «En impuls kan forstås som det som pirrer nysgjerrigheten, sansene og skapertrangen så sterkt at det oppstår et uttrykksbehov» (Sørenstuen, 2011, s. 119). Sett i lys av Kolb (2015) 


\section{A. S. Bernsen, A. Langøy E M. Eilifsen}

vil barnehagelæreres utgangspunkt for å iscenesette nye opplevelser i lekemiljøet for barna først bli til etter at de selv har skaffet seg egne opplevelser og kroppslige erfaringer. Deltagelse i de transformerte rommene blir dermed en del av den konkrete erfaringen. I oppstartsamlingen ble det gitt rom for diskusjon rundt erfaringen om hvordan nye og etablerte lekemiljøet kan oppleves, slik det neste utsagnet fra en annen barnehagelærer peker på:

Å se hvor mye det faktisk giør med deg, det rommet, så kan du tenke hvor mye det faktisk giør med et barn da. Å komme inn i et helt nytt rom, det var mye latter i de rommene.

Barnehagelæreren uttrykker en følelsesmessig erfaring, som beveger sinn og kropp, med latter som eksempel på aktivitetens utfall. Dette utsagnet viser refleksjon rundt egen kroppslig erfaring knyttet til opplevelsen. Nordtømme kaller dette fenomenet samhandling mellom barnet og rommet, noe personalet selv får erfare og reflektere over. Rom og materialitet settes i spill, og dermed får rommet betydning på nye måter (Nordtømme, 2016). Neste utsagn peker på mulighetene rommet åpner for:

Det er jo interessant, det er jo ikke alle som hadde begynt å kaste baller på en foreleser, etter et kvarter, hvis vi hadde vært i en forelesningssal [...] Altså rommet giør noe med hvordan vi agerer som voksne også.

Kroppslige handlinger og føringer opptrer i møtet med det iscenesatte rommet, noe som gjerne ikke ville ha oppstått hvis oppstartsdagen bare var teoribasert. Barnehagelærernes utsagn og refleksjoner viser til tenkningen om livsverdenen, der kroppen er utgangspunkt for erfaring (Merleau-Ponty, 1945/1994). Rommet åpner for en giensidig handling og en mer likestilt situasjon synliggjort ved at personalet kastet ball på forskerne. Spesielt i ballrommet viste forskningsdagboken at det kom frem mye latter og kommentarer som «gøy» og "dette var en kontrast som kjennes på kroppen». Utsagnene understreker at rommene åpner for å være kroppslig aktiv; en tilnærming som innbyr både til aktiv handling, interaksjon med hverandre og mye latter. Å relatere de konkrete erfaringene til egen praksis, kan si noe om å bli motivert for å implementere nye ideer.

I kommende sitat reflekterer en av barnehagelærerne over om handlinger og erfaringer ved avdelingen, og beskriver at leken var blitt rutinepreget:

Det var veldig lett å ta ut disse kassene fra hyllen. Vi var på gulvet, men det var ikke alltid, så ofte vi var engasjert.

Utsagnet antyder refleksjon over egne handlinger med bevisstgiøring av kropp i rom, til det passive og rutine pregede. Ifølge barnehagens rammeplan skal personalet ta utgangspunkt i barnas interesser og erfaringer når de velger temaer og prosjekter, og skal også bygge på kreativitet og lek og være åpne for improvisasjon (Kunnskapsdepartementet, 2017). Økt bevissthet og refleksjon over egen rolle i lekemiljøet kan være et 
utgangspunkt for å aktivere nye handlingsalternativer. Flere barnehagelærere forteller at de former lekemiljøer basert på barnas interesser og responsen som oppstår:

For å få det til å fungere har vi vært nødt til å se dypere på barnegruppen og hva de responderer på. Og for å ta det videre. For å se på barns medvirkning.

En barnehagelærer forklarer at på hennes avdeling tar personalet utgangspunkt i en bok som barna er opptatt av, og de konstruerer deler av avdelingens lekemiljø basert på boken. Deltagernes kroppslige erfaring i de transformerte rommen gjenspeiler seg videre i eksperimenteringen som tar til i barnehagehverdagen: «Noen av dere har kanskje merket at det henger olabukser, på vegger, tak, vinduer og på hyllene» og «Sokker har blitt sydd sammen til lange strimler som er hengt opp i taket». Disse sitatene viser at barnehagelærerne er inspirert av deltagelse og egne konkrete kroppslige erfaringer som de opplevde i de romlige møtene i starten av prosjektet. Eksperimentering og utprøving settes dermed ut i konkret, aktiv handling. Personalets kollektive kompetanse i en lærende barnehage synliggjøres og deles, noe som også gienspeiles i en av barnehagelærernes utsagn: «Jeg synes det var bra med dette at alle deltar».

\section{Funn 2: Kroppslig erfaring og kompetanse gir indre regulert motivasjon}

Barnehagelærerens refleksjoner rundt betydningen av å være bevisst på egen kompetanse viser seg som noe sentralt $i$ analysene våre. Oppstartsamlingen gir et felles startpunkt basert på aktiv deltagelse med både kroppslige erfaringer og teori, og en ønsker å skape motivasjon for nye handlinger i lekemiljøet. En barnehagelærer sa følgende:

Når vi møter noe nytt har vi få erfaringer, liten kompetanse i møte med dette nye. For å oppleve mestring vil vi da ofte gjøre det enkelt, bruke en oppskrift.

Dette utsagnet kan vise til en usikkerhet i møte med det nye som blir presentert, og sitatet kan tolkes i lys av teoridelen i oppstartsamlingen. I teoridelen refereres det til en prosessmodell fra et annet kunstnerisk utviklingsarbeid, med start og sluttprodukt (Bernsen, 2019). En slik modell kan være en hjelp i oppstart av nye prosjekter, men kan også oppleves som noe enkelt, som sitatet påpeker. Fra en annen barnehagelærer kom følgende refleksjon:

De som har tidligere erfaring i forhold til å endre rom har med dette skaffet seg en kompetanse. Dette gjelder både barn og voksne. Etter hvert som kompetansen øker vil vi også kunne være mer kreative og fri fra oppskrifter.

Utsagnet løfter frem kompetanse som en del av det å ha opplevd kreativitet. Økt erfaring og kompetanse kan gi mestringsopplevelser som motiverer til kreativitet og nyskaping.

Vi startet med det litt enkle, og så har vi fått oss kompetanse og så bygger vi på det. 


\section{A. S. Bernsen, A. Langøy \& M. Eilifsen}

Når barnehagelærerne har vært gjennom Kolbs erfaringssirkel én gang, vil de ved neste oppstart ha ny kompetanse, og sirkelen vil dermed fungere som en spiral. Opplevelsen av å ha tilegnet seg kompetanse, og selv være med å utforme nye prosjekter, vil ifølge selvbestemmelsesteorien (Deci \& Ryan, 2000) kunne fremme indre motivasjon. Det blir et prosjekt som i seg selv er kjekt å holde på med, slik som en barnehagelærer beskriver det:

Det var morsomt, spennende og motiverende å se. Ungene er i en sånn setting at de blir entusiastiske og vi får igjen for det arbeidet vi giør på ganske kort tid.

En annen barnehagelærer forteller at deres avdeling ble transformert til et høst-rom, med paraplyer hengende fra taket, oppblåsbart badebasseng med støvler $i$, små lyslykter og lyd av regn i bakgrunnen. De aller yngste barna var med å plukke løv som skulle benyttes som lekemateriell i rommet. De ansatte ble tydelig motivert av barnas reaksjoner da de så rommet:

Veldig interessant å se hvordan de reagerte når de kom inn i et rom som de forventer at dette skal være noe kjent.

Barnehagelærerne snakker videre om økt kompetanse:

Tenker at man øker sin egen kompetanse, fordi, alle blir mye mer bevisst på, sammenhengen mellom det fysiske rommet og lek og læring.

En annen i fokusgruppen forteller at kreativiteten merkes og at det tenkes mer på lekemiljøet:

[...] at jeg kanskje får frem litt kreativitet da [...] Jeg merker at jeg tenker mye mer giennom hvordan vi kan tilrettelegge rom og den type ting.

Flere trekker frem refleksjoner rundt eget arbeid, og det ser ut til at erfaringene fører til økt motivasjon, som igjen fører til engasjement:

Blir jo litt mer engasjert når du får egne ideer, egne tanker rundt det da. Det blir liksom ditt prosjekt, i stedet for at du får tildelt et, så blir du mer engasjert $i$ arbeidet.

Den positive og engasjerte fremstillingen av hvordan prosjektet blir ens eget, vil ut ifra selvbestemmelsesteorien vise et tilfredsstilt behov for autonomi. Engasjementet smitter, og personalet forteller at de innhenter ideer og kompetanse hos hverandre og blir inspirert seg imellom - har du sett hva de på den andre avdelingen har gjort? Eksempelet viser en drivkraft til å innhente kompetanse, også fra hverandre. Erfaringer deles; en type kunnskapsdeling som viser åpenhet om kunnskap en besitter.

Tidsaspektet ble trukket frem som en viktig faktor for å få til et felles prosjekt om lekemiljøet. Barnehagelærerne forklarte det slik: 
Tid er viktig for å bli motivert, liten tid er forbundet med stress, og at det går over så lang tid, det synes vi har vært veldig fint.

En annen barnehagelærer påpeker «at det vi ikke blir gode på etter et år eller noen måneder, er noe som vi kan bli gode på om vi fortsetter å ha fokus på det over tid». Utsagnene sier noe om at det er viktig å få tid til å dvele i prosessene, tid til å øke kompetanse, oppleve autonomi og skape tilhørighet til prosjektet. Hvis du lykkes med noe gir det utslag i en ny runde med eksperimentering, ifølge Kolb (2015). Hos Ryan \& Deci (2019) vil nettopp opplevelsen av å få tilfredsstilt disse tre behovene kunne være med på å skape en indre motivasjon for prosjektet og amotivasjon.

Barnehagelærerne sier at de av og til bommer litt når de prøver å få tak i barnas interesser: «Du tar fatt i det du har tolket. Av og til har vi gått litt i fallgruver». Det å gå i fallgruver er noe som hører til ethvert prosjekt. Motivasjon som aktiverer handling, som er det siste stadiet i erfaringssirkelen (Kolb, 2015), handler om å være med på å forme og bestemme selv. Mengden autonomi kan påvirke prosessen, noe som også vises i dette utsagnet fra en annen barnehagelærer:

Det hadde vært superbra hvis dere hadde vært og sett oss i aksjon med barna. Kanskje dere kunne veiledet oss litt i situasjonen. Av og til har vi tenkt, hvordan skulle vi gjort dette videre nå?

Sitatet illustrere hvordan for mye autonomi kan påvirke den opplevde kompetansen; her i form av å oppleve seg alene på en ny arena.

\section{Drøfting}

\section{Fra impuls til aktiv eksperimentering i rom}

Denne studien undersøkte barnehagelærernes aktive deltagelse $\mathrm{i}$ et prosjekt om hvordan endringer av lekemiljøet kan skape motivasjon og forståelse av rommets betydning for pedagogisk praksis. Data ble tolket i lys av erfaringslæringssirkelen til Kolb (2012) og selvbestemmelsesteorien til Deci og Ryan (1985, 2000). Vi som var forskere bevegde oss ut i barnehagefeltet, og slik oppsto et bindeledd mellom forskningsfeltet og praksis som muliggjorde kunnskapsdeling fra begge parter. Personalgruppen understreket viktigheten av et praksisfellesskap der alle deltar i barnehagens utviklingsarbeid, og der kunnskapen som formidles teoretisk skal videreføres og kroppsliggiøres.

Aktiv deltagelse i scenografier i de iscenesatte rommene var en essensiell del av prosjektet. Personalets aktive deltagelse utgjør den første delen av Kolbs læringssirkel. Det å delta i scenografiene gir selverfarte perspektiver på opplevelser og på kroppslige og sanselige erfaringer. Her tilegner hele personalet seg individuelle erfaringer for videre arbeid med kunnskapsdeling og læring. Ved å legge føringer, som å delta aktivt og leke i oppstartsdelen, åpnes det for at en gjennom kroppslig erfaring kan se lekemiljøet slik det fremstår for barna. Barnehagelærernes refleksjoner rundt 


\section{A. S. Bernsen, A. Langøy \&o M. Eilifsen}

egne erfaringer knyttes til diskusjonen rundt barnas kroppslige opplevelser i rom. Dette uttrykkes ved en umiddelbar reaksjon, en aha-opplevelse av å erfare et forandret lekerom i form av ulike iscenesettelser. Det åpnes for bevisstgjøring om rommets påvirkning for lek, og hvordan det materielle kan ha en aktiv og handlende rolle for læring. Denne aha-opplevelsen kan ses i sammenheng med en tenkning rundt erfaring som tar utgangspunkt $i$ at bevisstheten tar form bare gjennom kroppen. Eller, som Kolb selv uttrykker det; det er gjennom erfaringer læringen tar form. Erfaringen omdannes til erkjennelse ved at «det er en kombinasjon mellom å begripe en opplevelse og omdanne den» (Kolb, 2012, s. 296).

Barnehagelærerne reagerer ulikt i møte med de iscenesatte rommene, og en tenke seg at det også gjelder for barna. Det er ikke sikkert at en som voksen finner samme mening som et barn giør i et nytt lekemiljø, et transformert rom. En umiddelbar reaksjon fra personalet hentet fra forskningsdagboken uttrykker opplevelsen over hva rommet giør med deg som voksen, og reflekterer videre over hvordan det da vil oppleves for barna. Det som skapes av forståelse og oppdagelser kan dannes på bakgrunn av kroppslig erfaring, etterfulgt av tid for personalet til å reflektere over opplevelsene og erfaringene sammen. Dette er et viktig moment og en del av Kolbs erfaringslæring (stadium 2 og 3), og kan legge grunnlaget for indre drivkraft og motivasjon fra erfaring til aktiv handling. Gjennom oppfølging over ett år har vi sett at personalet har funnet nye måter å skape og iscenesette lekerom på.

\section{Fra kompetanse til kreativitet og motivasjon}

I analyseprosessene ble det synlig at økt kompetanse med eksperimentering med lekemiljøer førte til indre regulert motivasjon hos personalgruppen. Ordet kompetanse trekkes frem i flere tilfeller, motivasjon blir nevnt en gang, mens refleksjonene knyttes flere ganger til det faglige arbeidet i barnehagen. Barnehagelærerne beskriver hvordan økt kompetanse øker kreativiteten. Det at de opplever økt kompetanse gjennom erfaringer, og at det oppleves som motiverende, er med på å bekrefte antakelsene i selvbestemmelsesteorien. At mennesket er aktivt i sin søken etter å lære seg noe nytt og noe som kan være utfordrende, er en sentral antakelse i det teoretiske rammeverket til selvbestemmelsesteorien av Deci \& Ryan (2000). Dette rammeverket ser på motivasjon som en drivkraft som kan være både ytre og indre regulert, avhengig av $i$ hvor stor grad en opplever å få tilfredsstilt tre grunnleggende psykologiske behov: autonomi, kompetanse og tilhørighet. Å tendere mot indre regulert motivasjon vil si å oppleve at noe er motiverende i seg selv, at det er gøy å holde på med. Skal personalgruppen oppnå dette må de oppleve å mestre situasjonen, de må få påvirke situasjonen og de må trives sammen med folk de har rundt seg. Å være indre motivert har vist seg å være den formen for motivasjon som er mest holdbar over tid (Deci \& Ryan, 1985; Ryan \& Deci, 2019).

Gjennom å designe et prosjekt der personalgruppen selv fikk være med å utforme lekemiljøet på egen avdeling, la vi til rette for stor grad av autonomi. Personalet som skal arbeide etter Kolbs teori må få oppgaver utformet med hensyn til mest mulig 
frihet og autonomi i fremgangsmåten. Samtidig må oppgavene være passe utfordrende, slik at personalet opplever å få det til. I prosjektet skulle de lage lekemiljøer utformet med åpen inngang, noe som kan oppleves ulikt fra person til person. Det kom tilbakemeldinger om behov for mer oppfølging fra forskerne i prosjektet. Det kan indikere at prosjektet er for åpent og uttrykke et ønske om trygghet, eller å bli sett for å se om en er på rett vei. En fordel med et åpent prosjekt der hele personalet er aktive, er at en i stor grad legger til rette for et autonomistøttende miljø. Den kollegiale autonomien ble styrket ved at personalet fikk være med på å bestemme innholdet i prosjektet. Resultatet av prosjektet kunne blitt annerledes med andre forskere og faglærere fra andre fagfelt, og dersom det ble gjennomført i en annen barnehage. Samtidig gir forskningen svar på hva som kan motivere for eksperimenterende og utforskende praksis. Erfaringene både personalet og forskerne har tilegnet seg i prosjektet, har skjedd i en kultur og i et fellesskap. Data har dermed både katalytisk og pragmatisk validitet, i den forstand forskningen beveger både forskerne og personalet (Fangen, 2010).

Med utgangspunkt i Kolbs første stadium i erfaringssirkelen, spør vi om oppstartsamlingen er tilstrekkelig for å introdusere personalet for den aktive eksperimenteringsfasen. En mulig justering av oppstarten er å innhente innspill om ideer til de transformerte rommene fra personalet på forhånd. En annen innfallsvinkel kunne vært å konstruere scenografier basert på innspill fra personalgruppen. Mer inkludering av de ansatte kan gi en opplevelse av å komme mer på innsiden av prosjektet, og skape et sterkere eierforhold. Autonomien kunne blitt forsterket i oppstarten dersom alle i personalgruppen allerede fikk bidra med ideer til transformasjon allerede ved utarbeidelsen av oppstartsamlingen.

Et iscenesatt rom kan legge sterke og mindre sterke føringer med sin form og sitt utvalg av materiale. Den konkrete erfaringen kan forsterkes, noe som kan føre til inspirasjon til lignende arbeid i fremtiden. Ved tydelig inkludering av personalet $i$ oppstartsamlingen kunne noe av behovet og etterspørselen etter veiledning av eget arbeid blitt redusert. I en slik tenkt oppstart kan overraskelsesmomentet som ligger i å bli presentert for et nytt transformert rom utebli, og dermed også den viktige impulsen, ifølge Kolbs skjema. For å oppnå engasjement og forståelse (erkjennelse), ble de involverte presentert for både et teoretisk og et praktisk innhold. Det kom frem i dataene at balansen mellom teori og praksis fungerte godt. Data viser også at både forskere og personalet, gjennom felles deltagelse, får en opplevelse av å være i et mer likeverdig forhold under oppstartsamlingen. Hadde prosjektet utelukkende vært teoribasert, som en forelesning eller en kursrekke, ville det ifølge Kolbs læringssirkel ikke aktivisert til kroppslig erfaring i møtet med rommene. Engasjement for å sette i gang med aktiv eksperimentering kunne uteblitt. Oppstartsamlingen med fokus på både teori og lekbasert samling skaper refleksjon over kroppslige erfaringer og handlinger.

Prosjektet har et perspektiv som tilrettelegger for kollektive læringsprosesser med forankring i praksis, i motsetning til individuell læring med enkeltvis deltagelse på 


\section{A. S. Bernsen, A. Langøy $\mathcal{G}$ M. Eilifsen}

kurs. Personalet henter inspirasjon fra hverandre og på tvers av avdelingene, noe som kan skape en kunnskaps- og delingskultur innad i barnehagen. Når personalet deler erfaringer og kompetanse med hverandre og motiveres i praksisfellesskapet, fremmes også kunnskapsdeling i praksisfellesskapet. Erfaringslæring åpner for at personalet tester og utforsker ulike varianter av iscenesettelser av lekerom. Et nytt erfaringsgrunnlag danner igjen grunnlag for nye erfaringer. Vi kan se på dette som en form for eksperimentell læring som, ifølge Kolb, kan bli en kontinuerlig prosess der vi er kroppslig aktivt handlende og stadig lærende.

\section{Avslutning}

Artikkelen har sett på barnehagelærerens aktive deltagelse i et prosjekt om endringer av lekemiljøet i en barnehage og hva som skaper motivasjon og forståelse av rommets betydning for pedagogisk praksis. Studien beskriver en personalgruppe som er eksperimentell i sine utprøvinger av lekemiljøer, noe som åpner for kreativitet i tilretteleggingen av barns lekemiljø. Våre analyser viser at det gjennom aktiv deltagelse og medvirkning i kollektive prosesser over tid skapes motivasjon for endring av egen pedagogisk praksis hos personalet. Felles erfaring og konkret kroppslig erfaring skaper refleksjon rundt eget arbeid i barnehagen og gir økt kompetanse i å tilrettelegge for videre eksperimentering med lekemiljøer. Artikkelen viser også at økt kompetanse fører til indre regulert motivasjon i personalet. Barnas entusiasme motiverer personalet, som igjen fører til større grad av medvirkning fra barna i deres eget lekemiljø. Det oppstår en delekultur i personalet, og personalgruppen blir inspirert av hverandres arbeid. Artikkelen peker på et utvidet perspektiv på personalets rolle i tilknytning til rommets betydning, og setter søkelys på utforskende praksis med alternative lekemiljøer for barna.

\section{Forfatterbiografi}

Anette Sofie Bernsen er ansatt på NLA Høgskolen i Bergen der hun underviser i drama ved barnehagelærerutdanningen og er medlem av forskergruppen «Barn, Barnehage, Barnehagelærerutdanning». Bernsen er stipendiat på deltid ved Universitetet i Sørøst-Norge med forskningsfelt rettet mot lekemiljøet og rommets betydning i barnehagen hvor barns medvirkning og perspektiv kan komme til uttrykk.

Amund Langøy er høgskolelektor i fysisk fostring, og jobber som prorektor for utdanning ved NLA Høgskolen. Han er også ph.d.-kandidat ved Universitetet i Bergen tilknyttet HEMIL-senteret og den tverrfaglige forskningsgruppen «Social Influence Processes on Adolescent health» (SIPA). Forskningsprosjektet på UiB ønsker å tilføye mer til vår forståelse rundt faktorer som påvirker elever i 10 . klasse i Norge sin opplevelse av og deltagelse i kroppsøving. 
Margareth Eilifsen er førstelektor i pedagogikk og arbeider som studieprogramansvarlig for barnehagelærerutdanningen ved Høgskolen på Vestlandet. Hun er spesielt opptatt av studentenes utvikling og danning, og av arbeid med barnehageledelse med fokus på kompetanse blant personalet.

\section{Referanser}

Akker, J., Gravemeijer, K., McKenney, S. \& Nieveen, N. (2006). Introducing educational design research. I J. Akker, K. Gravemeijer, S. McKenney \& N. Nieveen (Red.), Educational design research (s. 3-7). Routledge.

Bernsen, A. S., Eilifsen, M. \& Langøy, A. (2014). Blikk for hverdagsrommet i barnehagen. I M. Eilifsen (Red.), På kryss og tvers. Muligheter ved flerfaglig arbeid $i$ barnehagen (s.118-132). Universitetsforlaget.

Bernsen, A. S. (2017). Lekne føtter i nye roller. Barnehagelærer som igangsetter med barnehagebarn som deltakere i demokratiske prosesser. I A. B. Sæbø, S. Eriksson \& T.-H. Allern (Red.), Drama, teater og demokrati. Antologi I. I barnehage, skole, museum og høyere utdanning (s. 125-139). Fagbokforlaget.

Bernsen, A. S. (2019). Barnas lekerom i forandring. I I. L. Møen \& E. Thoresen (Red.), Kunstpedagogisk utviklingsarbeid $i$ barnehagen. (s. 72-85). Fagbokforlaget.

Bjørnestad, E. \& Os, E. (2018). Quality in Norwegian childcare for toddlers using ITERS-R. European Early Childhood Education Research fournal, 26(1), 111-127. https://doi.org/10.1080/1350293X.2018.1412051

Bøe, M. \& Thoresen, M. (2017). A skape og studere endring: Aksjonsforskning $i$ barnehagen (2. utg.). Universitetsforlaget.

Deci, E. \& Ryan, R. M. (1985). Intrinsic motivation and self-determination in human behavior. Plenum.

Deci, E. \& Ryan, R. (2000). The "what» and "why» of goal pursuits: Human needs and the self-determination of behavior. Psychological Inquiry, 11(4), 227-268. https://doi.org/10.1207/S15327965PLI1104_01

Fangen, K. (2010). Deltagende observasjon (2. utg.). Fagbokforlaget.

Finlay, L. (2014). Engaging phenomenological analysis. Qualitative Research in Psychology, 11(2), $121-141$. https://doi.org/10.1080/14780887.2013.807899

Grindheim, L. T. (2014). Kvardagslivet til barneborgarar: ein studie av barna si deltaking $i$ tre norske barnehagar [Doktorgradsavhandling, Norges teknisk-naturvitenskapelige universitet]. NTNU Open. http://hdl. handle.net/11250/273981

Kolb, A. D. (2000). Den erfaringsbaserede læreproces. I K. Illeris (Red.), Tekster om laring (s. 47-66). Universitetsforlag.

Kolb, A. D. (2012). Erfaringslæring - processen og det strukturelle grundlag. I K. Illeris (Red.), 49 tekster om laring (s. 283-298). Samfundslitteratur.

Kolb, A. D. (2015). Experiential learning: Experiences as the source of learning and development. Pearson Education.

Kunnskapsdepartementet. (2017). Rammeplan for barnehagen - innhold og oppgaver. https://www.udir.no/ globalassets/filer/barnehage/rammeplan/rammeplan-for-barnehagen-bokmal2017.pdf

Kvale, S. \& Brinkmann, S. (2015). Det kvalitative forskningsintervju. Gyldendal Akademisk.

Meld. St. 19 (2015-2016). Tid for lek og laring. Bedre innhold i barnehagen. Kunnskapsdepartementet. https:// www.regjeringen.no/no/dokumenter/meld.-st.-19-20152016/id2479078/

Merleau-Ponty, M. (1994). Kroppens fenomenologi (B. Nake, Overs.). Pax. (Opprinnelig utgitt 1945)

Moser, T. (2012). Barnehagens innerom som pedagogisk utviklingsprosjekt. I A. Krogstad, G. K. Hansen, K. Høyland \& T. Moser (Red.), Rom for barnehage - et flerfaglig perspektiv på barnehagens fysiske miljø (s. 129-146). Fagbokforlaget.

Nordin-Hultman, E. (2004). Pedagogiske miljøer og barns subjektskaping. Pedagogisk forum.

Nordtømme, S. (2016). På vei mot en rom(s)lig pedagogikk: En fortolkende studie av barns lekeerfaringer med rom og materialitet [Doktorgradsavhandling, Høgskolen i Sørøst-Norge]. USN Open Archive. http://hdl.handle. net/11250/2373513

O'Toole, J. (2006). Doing drama research: Stepping into enquiry in drama, theatre and education. Drama Australia.

Ryan, R. M. \& Deci, E. L. (2017). Self-determination theory: Basic psychological needs in motivation, development, and wellness. Guilford Publications. 


\section{A. S. Bernsen, A. Langøy \& M. Eilifsen}

Ryan, R. M. \& Deci, E. L. (2019). Brick by brick: The origins, development, and future of self-determination theory. I A. Elliott (Red.), Advances in motivation science (Bd. 6, s. 111-156). Elsevier.

Sando, O. J. \& Sandseter, E (2020). Affordances for physical activity and well-being in the ECEC outdoor environment. Fournal of Environmental Psychology, 69. https://doi.org/10.1016/j.jenvp.2020.101430

Sørenstuen, J.-E. (2011). Levende spor: Å oppdage naturen gjennom kunst, og kunsten gjennom natur. Fagbokforlaget.

Ødegård, E., Nordahl, J. \& Røys, H. (2017). Alle skal med! Veiledning $i$ den lerende barnehage. Cappelen Damm Akademisk.

Øvreås, S., Andersen, E., Moser, T., Borch-Jenssen, J. \& Jørgensen, K.-A. (2020). Å styrke fysisk aktiv lek i barnehagen - evaluering av et intervensjonsdesign basert på en høy grad av personaldeltagelse. Nordisk tidsskrift for utdanning og praksis, 14(1), 134-154. https://doi.org/10.23865/up.v14.2090 